\title{
A study on the etymology of the scientific names given to planarians (Platyhelminthes, Tricladida) by Ernest Marcus' school
}

\author{
Priscila Donegá Jasper ${ }^{1,3}$; Eudóxia Maria Froehlich², \& Fernando Carbayo ${ }^{1,4}$ \\ 1 Universidade de São Paulo (USP), Escola de Artes Ciências e Humanidades (EACH), Laboratório de Ecologia e Evolução. São Paulo, SP, Brasil. \\ 2 Universidade de São Paulo (USP), Instituto de Biociências (IB-USP), Departamento de Zoologia. São Paulo, SP, Brasil. E-mail: emfroeh@ib.usp.br \\ ${ }^{3}$ ORCID: http://orcid.org/0000-0003-4199-1528. E-mail: saxpri@hotmail.com \\ ${ }^{4}$ ORCID: http://orcid.org/0000-0002-8524-9715. E-mail: baz@usp.br \\ † 21 0ctober 1929, 26 September 2015.
}

\begin{abstract}
Leading zoologist and taxonomist Ernest Marcus (1893-1968) and his school described numerous new invertebrate taxa, including planarians, or triclads (Platyhelminthes). These authors rarely provided the etymology of names for the new taxa. In this paper, the etymology of 149 names of genera and specific epithets of planarians lacking etymology (or honoring people) is investigated. The etymology of most names was retrieved from original descriptive papers and from Eudóxia Maria Froehlich's recollections, a fellow of Marcus' school. It was discovered that the names were usually freely derived from words of the language spoken in the country where the species was found. Some names were motivated by an aspect of the biology of the species. Other names honored people or are arbitrary. The etymology of 19 names could not be retrieved and are only suggested. The origin of another 19 names could not be discovered, nor even their meaning. Knowing the etymology makes it easier to memorize a name and it is a way to preserve the historical and emotional aspects of the authors. Through the retrieved etymologies, the personality of Marcus can also be glimpsed.
\end{abstract}

Key-Words. Classification; Nomenclature; Geoplana; Historiography; Taxonomy.

\section{INTRODUCTION}

Roots may be formed in several ways Foucault, 1994, The order of things

From the dawn of history, humans were already taxonomists. By distinguishing linguistically food from non-food, potential predators from non-predators, they increased survival chances (Dunn \& Davison, 1968; Raven et al., 1971). It was Linnaeus's binomial nomenclature in the $18^{\text {th }}$ century that made species names universal. Over 1.87 million species have received a scientific name, of which 1.28 are animals (http://www.catalogueoflife.org/col, access: 25/07/2020). Estimates point to about 7.77 million animal species on Earth (Mora et al., 2011), 76\% of them not yet described. New species need a new name. For animals, the International Code of Zoological Nomenclature, or the Code (ICZN, 1999) regulates nomenclatural acts and etymological rules of new names at ranks between subspecies and family level. The origin of a name given to a taxon is called derivation or etymology. Coining a name is probably the only place for taxonomists to express themselves freely and creatively. The Code provides support for that: "A name may be a word in or derived from Latin, Greek or any other language (even one with no alphabet) or be formed from such a word. It may be an arbitrary combination of letters providing this is formed to be used as a word" (Art. 11.3, ICZN, 1999). Authors are not obliged to provide the etymology of new names, since it is only a recommendation (Recommendation 25C of ICZN, 1999). The same is true for Botanists and the International Code of Nomenclature for algae, fungi, and plants (Recommendation 60H.1, Turland et al., 2018), but not for bacteriologists, who must give the derivation of a new name (Rule 27b, Parker et al., 2019). Nevertheless, some taxonomic journals expressly require from authors to give the etymology of new names (e.g., European Journal of taxonomy, https://europeanjournaloftaxonomy.eu/index.php/ejt; Zookeys, https://zookeys.pensoft.net; Zoologia https:// www.scielo.br/revistas/zool/iinstruc.htm; access: 03/08/2020) or to follow the rules and recommendations of the Code (e.g., this journal).

Authors of new names usually evoke a biological aspect of the species named, such as mor- 
phological, behavioral or the geographical origin of the species. Authors may also honor someone deserving respect, or they simply give humorous or peculiar names which have nothing to do with the species being named (Ohl, 2018).

For taxonomists, names based on a biological aspect may make the name easy to memorize. For historiographers, etymology of names may help discover aspects of the author giving the name. However, in the past, taxonomists did not always provide the etymology of the new names of animals. This is the case of the school of Prof. Ernest Marcus (1893-1968) for the free-living flatworms (Platyhelminthes) they studied.

German-born, Marcus was Zoologist and professor at the Institute of Zoology at the University of Berlin. Further biographical accounts are found in Mendes (1994), Carbayo et al. (2009) and Winston (2002). In 1936 Marcus and his wife, Eveline du Bois Raymond-Marcus (1901-1990) moved to São Paulo, Brazil, where they wrote a "monumental monographic work of South American micro- and macroturbellarians" (Rieger, 1998). Between 1936 and 1968 they published 162 papers in Brazil on several animal Phyla (Mendes, 1994). Marcus mentored prominent zoologists (Winston, 2002; Carbayo et al., 2009). He also founded a Brazil-based productive school of morphology and systematics of free-living flatworms, composed of Eveline du Bois-Reymond Marcus, Claudio Gilberto Froehlich, Eudóxia Maria Froehlich (1928-2015), Diva Diniz Corrêa (1918-1993) and Maria Elisa Quissak Martins. Between 1946 and 1978, Marcus's school published several papers with the description of numerous species and genera of planarians, or triclads (Tricladida, Platyhelminthes), besides further works on additional flatworms and other phyla. The etymology of the new names was rarely revealed by them. The purpose of the present work is to investigate the etymology of triclad names given by Marcus' school.

\section{MATERIAL AND METHODS}

We circumscribed the reporting period to 1946-1978, 1946 being the first year that a paper on triclads was published, and 1978 the last paper before etymology of new names was regularly provided. We produced a list of generic and specific epithets of planarians given by Marcus' school, from the species and genera compiled in Carbayo et al. (2009), Carbayo \& Froehlich (2008) and Tyler et al. (2006-2013) lacking etymology. In this list we maintained names of species honoring personalities as a contribution to the historiography.

We read the papers with original descriptions in search of clues of the etymology. We explored Eudóxia's recollections as she lived with Marcus and Eveline since the late 1940 until Marcuses' decease. We recorded her memories about the etymology in two situations: intermittently when the issue arose during the meetings with FC over the last ten years of her life, and on two formal scheduled interviews with PDS. Subsequently, we checked the meaning of the epithets in Quechua, English, Kukama-Kukamiria, Latin, Portuguese, Spanish, and Tupi dictionaries and lexicons (Ajacopa, 2007; Lewis \& Short, 1879; Brown, 1956; Bueno, 1998; Collins, 2014; Gregório, 1980; Houaiss, 2001; RAE, 2020; Tibiriçá, 1984; Vallejos \& Amías, 2015). Claudio Gilberto Froehlich checked the etymologies of a preliminary glossary and provided the derivation of some epithets.

We assembled the names and their etymologies in a glossary, with each name fitting one of four categories according to the motivation: names derived from characteristics of the species (including size, shape, color, morphology, habitat, locality); commemorative names; arbitrary names, and names with putative etymology, the latter cases indicated with 'prob' in the glossary. For each entry of the glossary, we provided the original species name or the genus name, authority, year of publication, etymology, and the country where the taxon (species or genus) was originally found. We omitted from the glossary epithets from which both their meaning and motivation remain elusive.

\section{RESULTS AND DISCUSSION}

We found 149 triclad epithets (133 specific epithets, 16 of genus level) given by Marcus (47), Froehlich, C.G. (39), du Bois-Reymond Marcus (30), Froehlich, E.M. (27), Marcus \& du Bois-Reymond Marcus (3), Corrêa (2), and
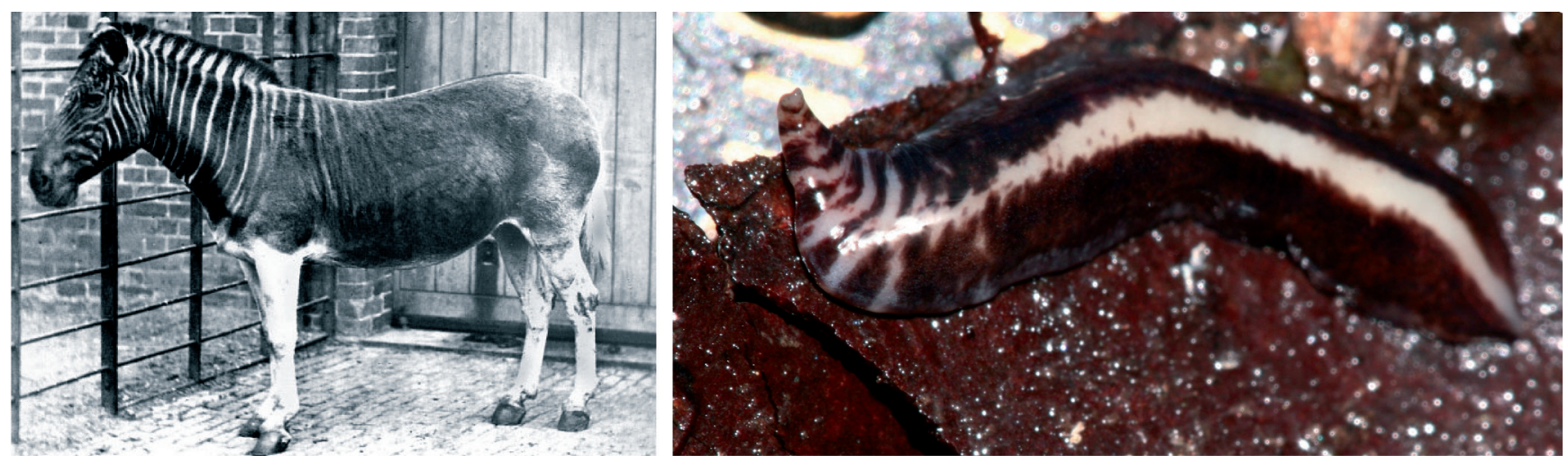

Figure 1. Pictures of the extinct Quagga, Equus quagga quagga (https://commons.wikimedia.org/wiki/File:Quagga photo.jpg) (left) and the 3-cm long land planarian Geoplana quagga Marcus, 1951 (right). Note the similar color pattern of the head. 


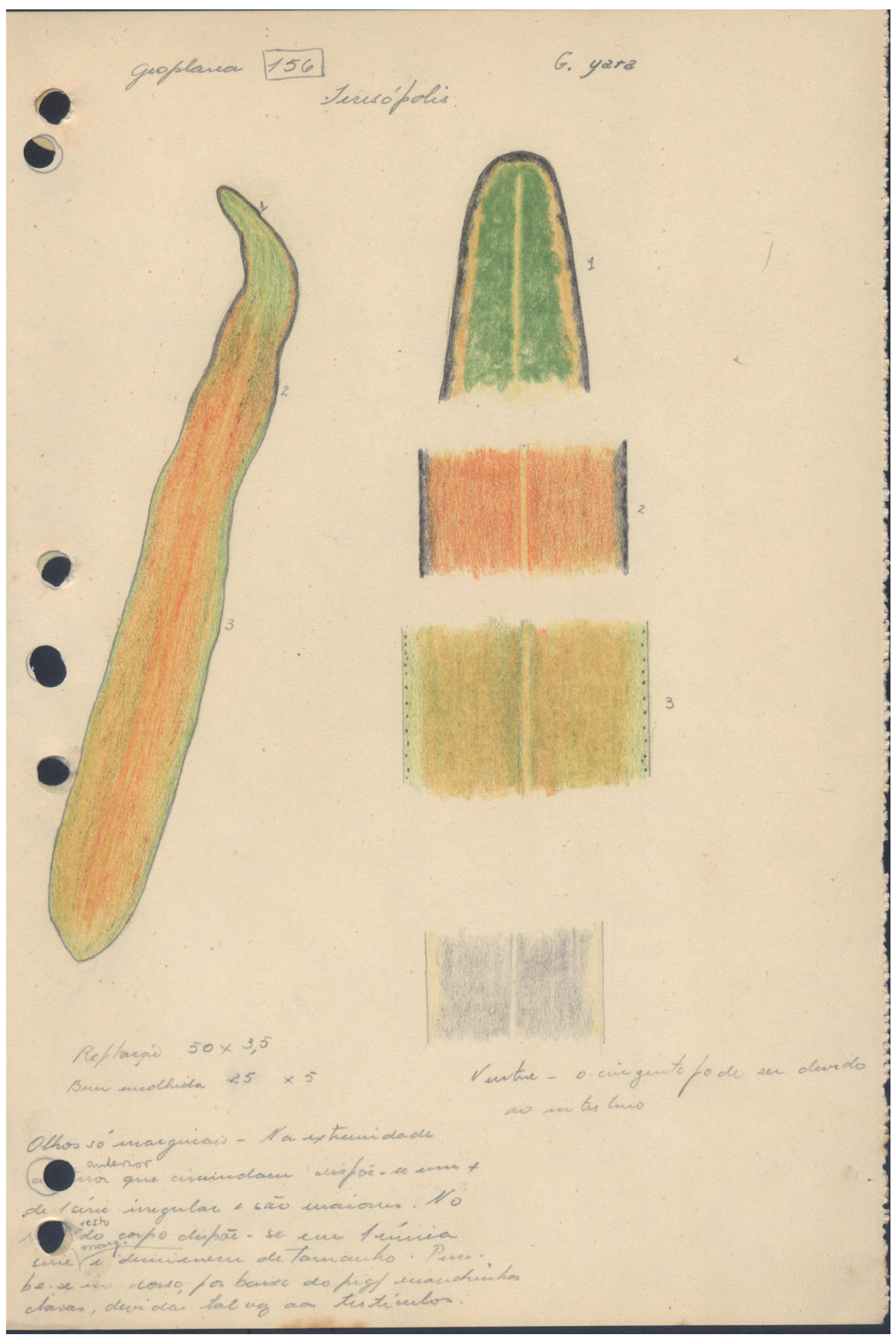

Figure 2. Hand drawings by Froehlich, E.M. of the live Geoplana yara. The green cephalic region motivated the author to use the specific epithet after lara, the greenhaired Amazonian mermaid in the Brazilian folklore. 

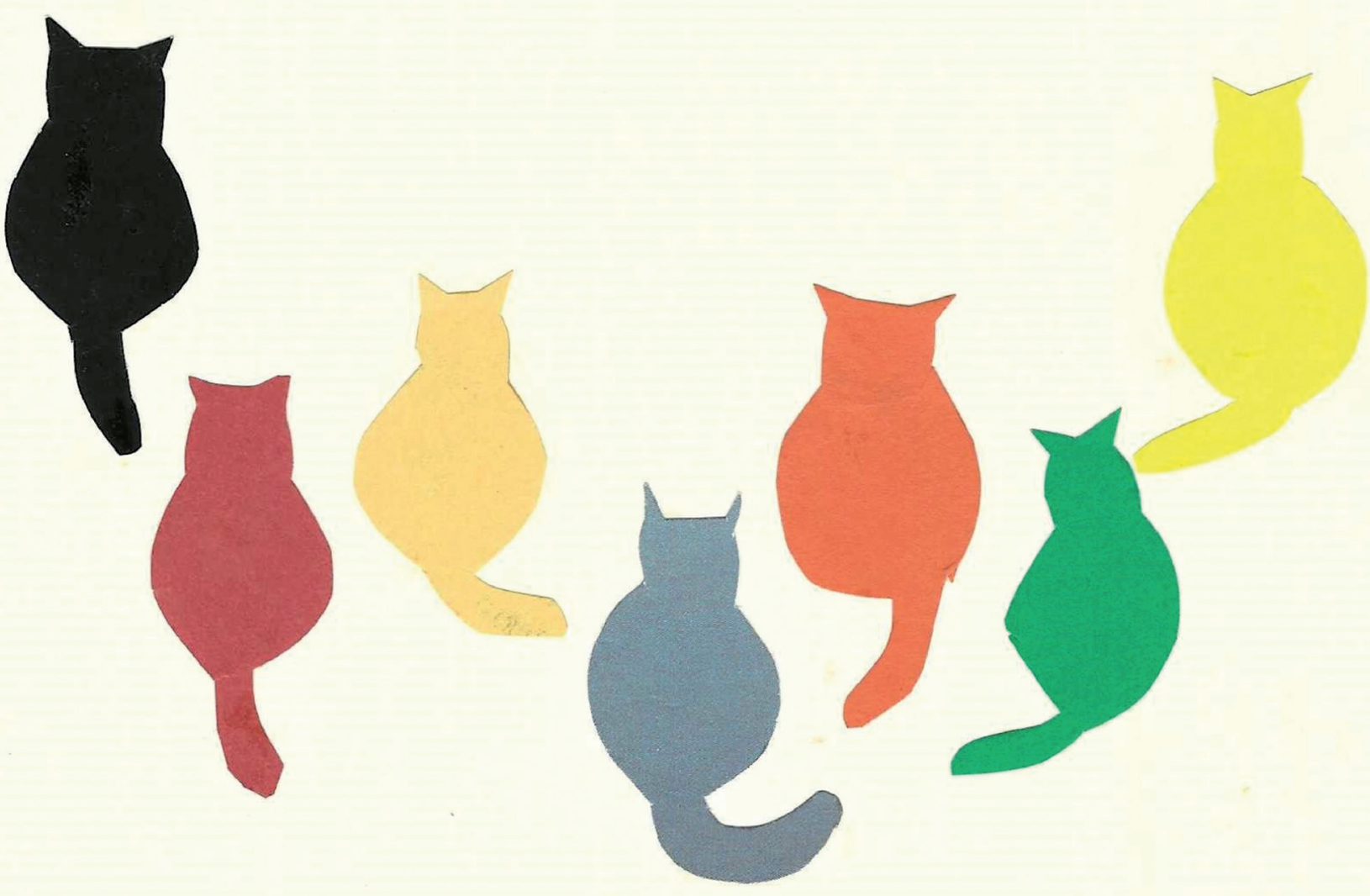

$26 \cdot \bar{x} 11.83$

Dear Leigh and Fannily

Chany thanks for Jeason's freetings. a peacefol 1984

very Anly 
Martins (1). This assignment is not a fully accurate picture of authorship, for Marcus signed alone in papers but his wife's coauthorship is expressed clearly in relevant taxonomic papers (e.g., Marcus, 1947, 1951; see also Edmunds, 1991).

Biology: Fifty epithets were prompted by an aspect of the biology of the species, such as the body shape and size (apeva, assu, cassula, chimbeva, chiuna, fita, Gusana, hystrix, Issoca, Liana, mirim, nana, Timyma, Xerapoa) the color of the body (astraea, astrocheta, bilix, cafusa, chita, crioula, hypoglauca, joia, Leucolesma, leucophryna, livia, nigra, picta, pinima, piranga, plumbea, quagga (see Fig. 1), rosea, ruiva, tapetilla, tinga, trigueira, trina, una, yara, see Fig. 2), the internal morphology (monomyoda, ectophysa, Incapora), and the habitat or geographical origin (caapora, caissara, gaucha, Kontikia, matuta, orana, piptus, tapira). The Marcuses avoided giving names describing morphological characters (du Bois-Reymond Marcus, 1987). Indeed, this practice was little used by them (astraea, astrocheta, bilix, ectophysa, hypoglauca, Incapora, leucophryna, monomyoda, quagga, tinga, trina).

Commemorative: Other epithets honored people (34) who somehow helped the authors (beckeri, Dinizia, divae, fragai, glieschi, graetzi, hauseri, jimi, marthae, moei, mourei, nataliae, pavani, phocaica, righii, rudebecki, saegeri, schubarti, weyrauchi) or who are authorities in their respective research fields (arndti, carvalhoi, corderoi, dahli, hymanae, libbieae, nonatoi, oliverioi, riesteri). Sometimes, the people honored are family members (e.g., juliae, regia). Marcus honored his wife several times with variations of her name (evelinae, velina) or her affectionate nicknames (Nerpa, phocaica; see also Winston, 2002). Moreover, he paid homage to his wife 74 times by giving the name evelinae to the respective turbellarian non triclad species (see Tyler et al., 2006-2013).

Arbitrary: Twenty-five epithets are arbitrary. Some of these names are related with things loved by the authors, as is the case of the Marcuses' passion for small mammals (harea, voleum), especially cats (Miava, misus, Tiddles). Eveline's love for cats is well known (Edmunds, 1991; Fig. 3). Other arbitrary names were coined from euphonic words derived from the vernacular idiom spoken in the local origin of the species. Thus, Brazilian species were given names from the Brazilian Portuguese (duca, suva, Vatapa), classic languages (pasipha, taxiarcha), and Tupi (catua, jandaia, jandira, potyra, toriba, tuxaua; but see perereca, Timyma and tinga for exceptions). In turn, Peruvian species received names derived from the Spanish spoken in Peru (aymara, lama, quichua) whereas those from Chile received words common in that country (caleta, guasa, placilla).

Unknown: We could not retrieve the origin of 24 names, yet the motivation is suggested. Some of them are similar to words spoken in the country of origin of the species (chanca, chilla, ercilla, quenua, rincona (Chile), cantuta, caya, chalona, chulpa, garua, irua, lambaya, pichuna, shapra, takia, vicuna, yaravi (Peru), poca, Rhodax (Brazil). A few names were seemingly derived from an aspect of their biology (conyum, parca, polecatum, pugum). Presumably the name scius is arbitrary. The putative etymology of these names is indicated with 'Prob.' (see Glossary).

Finally, we could not discover the origin of 15 names, nor even their meanings. Taxa with names in this category are from Brazil (Bopsula, camica), Peru (chiliua, idaia, lareta, saima, talpa, vircata), Portugal (sameha), and South Africa (chinum, gnaum, huntum, paeta, wauzen, wimbimba) (du Bois-Reymond Marcus, 1951, 1955, 1958; Froehlich, E.M., 1955; Marcus, 1946, 1953, 1955a, 1970; Marcus \& du Bois-Reymond Marcus, 1959). Probably, some of these names were imaginatively created, as might be the case for Puiteca, a word resembling the name of the sea slug genus Piseinotecus, which in Portuguese means "I stepped onto Teco [name of Marcuses' dog]" (du BoisReymond Marcus, 1987).

In his school, Marcus was most prolific in describing and naming new taxa and explored both the freedom and the artistic perspectives supported by the Code (Art. 11.3, ICZN, 1999). A glimpse of his personality can be caught through the etymologies of the names he gave: cultured (e.g., pasipha, taxiarcha), humorous (Miava, Nerpa, piptus), lovely (largely used evelinae), lover of animals (harea, polecatum, voleum), ingenious (astrocheta, ectophysa, monomyoda), and admirer of researchers ( $p a-$ vani, arndti, corderoi, Dinizia, divae).

The etymology of other names given by the Marcuses and Froehlich, C.G. to other taxonomic groups, including other platyhelminths and another phyla still remains to be investigated (e.g., Marcus, 1938; du Bois-Reymond Marcus, 1956; Froehlich, C.G., 1968, 1969; see also Mendes, 1994; Corrêa, 1991).

A scientific name depicts the creative pinnacle of a taxonomic work, and the etymological meaning may be of historical or emotional interest (Ohl, 2018). Independently from requirements of the nomenclatural codes, we advocate the disclosure of the etymology of new names at the time of proposing a new taxon. Otherwise, the meaning of a name may well be lost in forgotten memories.

Through this study, we hope to contribute to preserving these historical and creative aspects of Ernest Marcus - one amongst the most prominent zoologists of the $20^{\text {th }}$ century (Sawaya, 1970; Mendes, 1994; Zarur, 1994) - and those of his school.

\section{ACKNOWLEDGEMENTS}

We thank Prof. Iván Angues Bambarén and José $\mathrm{H}$. Grau (guest researcher, Evolutionary Adaptive Genomics, Institute of Biochemistry and Biology, University of Potsdam, Potsdam, Germany) for their valuable advices on Peruvian and Chilean vernacular words, respectively. Leigh Winsor (University James Cook, Australia) is thanked for kindly providing a copy of Eveline's postcard 
and for his help with some English-derived epithets. Claudio Gilberto Froehlich (University of São Paulo) is also thanked for sharing his memories on the etymology of some names. Rodrigo H. Willemart (University of São Paulo) and Domingo Lago-Barcia are sincerely thanked for their comments on a draft of this article. FC has financial support of FAPESP (proc. 2019/12357-7). We extend our thanks to an anonymous reviewer for her/his constructive comments and suggestions. This article is dedicated to the memory of Prof. Sérgio Antônio Vanin, who also reviewed the article.

\section{AUTHORS' CONTRIBUTIONS}

PDJ: Methodology, Data analysis, Writing, Review and Editing. EMF:Data analysis, Writing. FC:Conceptualization, Methodology, Data analysis, Supervision, Writing, Review and Editing. All the authors actively participated in the discussion of the results, PDJ and FC reviewed and approved the final version of the paper.

\section{CONFLICTS OF INTEREST}

Authors declare there are no conflicts of interest.

\section{REFERENCES}

Ajacopa, T.L. 2007. Diccionario Bilingüe quechua - castellano. La Paz.

Brown, R.W. 1956. Composition of scientific words. Washington, Smithsonian Books.

Bueno, F.S. 1998. Vocabulário tupi-guarani português. 6. ed. São Paulo, Éfeta Editora.

Carbayo,F.\&Froehlich, E.M. 2008. Estado do conhecimento dosmacroturbelários (Platyhelminthes) do Brasil. Biota Neotropica, 10: 1131-1134. D0I

Carbayo, F.; Froehlich, E.M.; Leal-Zanchet, A.M. \& Amato, S.B. 2009. Turbelários (Platyhelminthes). In: Rocha, R. \& Boeger, W. (Orgs.). Estado da Arte e Perspectivas para a Zoologia no Brasil. Curitiba, Editora UFPR. p. 49-64.

Collins, 2014. Complete and unabridged English dictionary. 12. ed. HarperCollins Publishers. Available: https://www.collinsdictionary.com/ dictionary/english. Access: 07/2020.

Corrêa, D.D. 1947. A primeira Dolichoplana (Tricladida, Terricola) do Brasil. Boletins da Faculdade de Filosofia, Ciências e Letras, Universidade de São Paulo, Série Zoologia, 12: 57-81. D0I

Corrêa, D.D. 1960. Two new marine Turbellaria from Florida. Bulletin of Marine Science of the Gulf and Caribbean, 10: 208-216.

Corrêa, D.D. 1991. Dr Eveline du Bois-Reymond Marcus. Hydrobiologia, 227: xxiii-xxvi. DOI

du Bois-Reymond Marcus, E. 1951. On South American Geoplanids. Boletins da Faculdade de Filosofia, Ciências e Letras da Universidade de São Paulo. Série Zoologia, 16: 217-255.

du Bois-Reymond Marcus, E. 1953. Some South American Triclads. Anais da Academia Brasileira de Ciências, 25: 65-78.

du Bois-Reymond Marcus, E. 1955. On Turbellaria and Polygordius from the Brazilian coast. Boletins da Faculdade de Filosofia, Ciências e Letras da Universidade de São Paulo. Série Zoologia, 20: 19-53. DOl

du Bois-Reymond Marcus, E. 1956. On some Prosobranchia from the coast of São Paulo. Boletim do Instituto Oceanográfico, 7: 3-29. D01 du Bois-Reymond Marcus, E. 1957. On Turbellaria. Anais da Academia Brasiliera de Ciências, 29: 153-191.

du Bois-Reymond Marcus, E. 1958. On South American Turbellaria. Anais da Academia Brasileira de Ciências, 30: 391-417.

du Bois-Reymond Marcus, E. 1965. Drei neue neotropische Turbellarien. Sitzungsberichte der Gesellschaft Naturforschender Freunde zu Berlin (N.F), 5: 129-135.

du Bois-Reymond Marcus, E. 1987. Selected recollections from my life. American Malacological Bulletin, 5: 183-184. https://archive.org/details/ biostor-143173.

Dunn, R.A.\& Davidson, R.A. 1968. Pattern recognition in biologic classification. Pattern Recognition, 1:75-93. D0I

Edmunds, M. 1991. Obituary - Eveline du Bois Reymond Marcus, 1901-1990. Journal of Moluscan Studies, 57: 141-142. D01

Froehlich, C.G. 1955a. Sôbre morfologia e taxonomia das Geoplanidae. Boletins da Faculdade de Filosofia, Ciências e Letras, Universidade de São Paulo, Série Zoologia, 19: 195-279. DOl

Froehlich, C.G. 1955b. Notas sôbre geoplanas brasileiras. Papéis Avulsos do Departamento de Zoologia, Secretaria de Agricultura, 12: 189-198.

Froehlich, C.G. 1956a. Tricladida Terricola das regiões de Teresópolis e Ubatuba. Papéis Avulsos do Departamento de Zoologia, Secretaria de Agricultura, 12: 313-344.

Froehlich, C.G. 1956b. Planárias terrestres do Paraná. Dusenia, 7: 173-196.

Froehlich, C.G. 1957. On a collection of Brazilian land planarians. Boletins da Faculdade de Filosofia, Ciências e Letras, Universidade de São Paulo, Série Zoologia, 21: 93-121. DOI

Froehlich, C.G. 1959. On geoplanids from Brazil. Boletins da Faculdade de Filosofia, Ciências e Letras, Universidade de São Paulo, Série Zoologia, 22: 201-265. DOI

Froehlich, C.G. 1968. On some Brazilian Onychophores. Beiträge zur Neotropischen Fauna, 5: 160-171. D01

Froehlich, C.G. 1969. Caenis cuniana sp. n., a Parthenogenetic Mayfly, Beiträge zur Neotropischen Fauna, 6:2: 103-108.

Froehlich, E.M. 1955. Sôbre espécies brasileiras do gênero Geoplana. Boletins da Faculdade de Filosofia, Ciências e Letras, Universidade de São Paulo, Série Zoologia, 19: 289-369. D0I

Froehlich, E.M. 1978. On a collection of Chilean landplanarians. Boletim de Zoologia, 3: 7-80. DOI

Froehlich, E.M. \& Froehlich, C.G. 1972. Land planarians from the Amazonian Region. Papéis Avulsos do Departamento de Zoologia, Secretaria de Agricultura, 26: 29-45.

Gregório, J. 1980. Contribuição indígena ao Brasil. Belo Horizonte, União Brasileira de Educação e Ensino. 3 v.

Houaiss, A. 2001. Dicionário Houaiss da Língua Portuguesa. Elaborado no Instituto Antonio Houaiss de Lexicografia e Banco de Dados da Portuguesa. Rio de Janeiro, Objetiva.

International Commission on Zoological Nomenclature (ICZN), 1999. International Code of Zoological Nomenclature. 4. ed. The International Trust for Zoological Nomenclature 1999. Available: https://www.iczn. org. Access: 07/2020.

Lewis, C.T \& Short, C. 1879. A Latin Dictionary. Clarendon Press, Oxford.

Marcus, E. 1938. Bryozoarios marinhos Brasileiros II. Boletins da Faculdade de Filosofia, Ciências e Letras, Universidade de São Paulo, Série Zoologia, 4: 1-196. DOI

Marcus, E. 1946. Sobre Turbellaria brasileiros. Boletins da Faculdade de Filosofia, Ciências e Letras, Universidade de São Paulo, Série Zoologia, 11: 5-253. DOI

Marcus, E. 1947. Turbelários marinhos do Brasil. Boletins da Faculdade de Filosofia, Ciências e Letras, Universidade de São Paulo, Série Zoologia, 12: 99-215. DOI 
Marcus, E. 1948. Turbellaria do Brasil. Boletins da Faculdade de Filosofia, Ciências e Letras, Universidade de São Paulo, Série Zoologia, 13: 113-243. DOI

Marcus, E. 1951. Turbellaria brasileiros (9). Boletins da Faculdade de Filosofia, Ciências e Letras, Universidade de São Paulo, Série Zoologia, 16:5-215. D0I

Marcus, E. 1952. Turbellaria brasileiros (10). Boletins da Faculdade de Filosofia, Ciências e Letras, Universidade de São Paulo, Série Zoologia, 17:5-187. D0I

Marcus, E. 1953. Turbellaria Tricladida. In: Exploration du Parc National de I'Upemba. Mission GF De Witte (1946-1949). Inst Parcs Nationaux du Congo Belge, 21: 3-62.

Marcus, E. 1954. Turbellaria Brasileiros - XI. Papéis Avulsos do Departamento de Zoologia, Secretaria de Agricultura, 24: 419-489.

Marcus, E. 1955a. Turbellaria. South African Animal Life (Results of the Lund University Expedition of 1950-51) I, 3: 101-151.

Marcus, E. 1955b. Turbellaria. In: Exploration du Parc National de la Garamba, Mission H. de Saeger (1949-1952), Fasc. 3: 1-31.

Marcus, E. 1963. Eine neue Meerestriklade von Sao Paulo. Zoologische Beiträge, 9: 441-446.

Marcus, E. 1970. Turbellaria (addenda). South African Animal Life (Results of the Lund University Expedition of 1950-51), 14: 9-18.

Marcus, E. \& du Bois-Reymond Marcus, E. 1959. Turbellaria from Madeira and The Azores. Boletim do Museu Municipal do Funchal, 12: 15-42.

Martins, M.E.Q.P. 1970. Two new species of Dugesia (Tricladida Paludicola) from the State of São Paulo, Brazil. Anais da Academia Brasileira de Ciências, 42: 113-118.

Mendes, E.G. 1994. Ernest Marcus. Estudos Avançados, 8: 209-213. D0I

Mora, C.; Tittensor, D.P.; Adl, S.; Simpson, A.G.B. \& Worm, B. 2011. How many species are there on Earth and in the Ocean? PLoS Biololy, 9, e1001127. D0I

Ohl, M. 2018. The Art of Naming. Cambridge, Mass., The MIT Press.

Parker, C.T.; Tindall, B.J. \& Garrity, G.M. 2019. International Code of Nomenclature of Prokaryotes. International Journal of Systematics and Evolutionary Microbiology, 69: S1-S111. D0I
Raven, P.H.; Berlin, B. \& Breedlove, D.E. 1971. The origins of taxonomy. Science, 174: 1210-1213. DOI

Real Academia Española (RAE), 2020. Diccionario de la lengua española. 23. ed., [online version 23.3]. Available: https://dle.rae.es. Access: $26 / 07 / 2020$.

Rieger, R.M. 1998. 100 Years of Research on 'Turbellaria'. Hydrobiologia, 383: $1-27$.

Sawaya, P. 1970. Professor Ernest Gotthelf Marcus. Boletim do Instituto de Biociências da Universidade de São Paulo. Nova Série, Zoologia e Biologia Marinha, 27: 7-18. DOI

Tibiriçá, L.C. 1984. Dicionário Tupi-Português. São Paulo, Traço Ed.

Turland, N.J.; Wiersema, J.H.; Barrie, F.R.; Greuter, W.; Hawksworth, D.L.; Herendeen, P.S.; Knapp, S.; Kusber, W.H.; Li, D.Z.; Marhold, K.; May, T.W.; McNeill, J.; Monro, A.M.; Prado, J.; Price, M.J. \& Smith, G.F. (Eds.). 2018. International Code of Nomenclature for algae, fungi, and plants (Shenzhen Code) adopted by the Nineteenth International Botanical Congress Shenzhen, China, July 2017. Regnum Vegetabile 159. Glashütten, Koeltz Botanical Books. Available: https://www.iapt-taxon.org/nomen/main. php. Access: 07/2020.

Tyler, S.; Schilling, S.; Hooge, M; \& Bush, L.F. (Comp.). 2006-2013. Turbellarian taxonomic database. Version 1.7 Available: http://turbellaria.umaine. edu. Access: 07/2020.

Vallejos, R. \& Amías, R. 2015. Diccionario Kukama-Kukamiria - castellano. Iquitos, AIDESEP/ISEPL.

Winston, J.E. 2002. Ernst Gustav Gotthelf Marcus (1893-1968) and Eveline Agnes du Bois-Reymond Marcus (1901-1990). In: Jackson, P.N.W \& Jones, M.E.S. (Eds.). Annals of Bryozoology: aspects of the history of research on bryozoans. International Bryozoology Association, Dublin, 339-361. Available: http://bryozoa.net/annals/annals1/index.html. Access: 07/2020.

Zarur, G.dC.L. 1994. Schools and paradigms in Brazilian Zoology. Interciencia, 19: 183-190. 


\section{APPENDIX}

\section{Glossary}

For each entry of the glossary, there are provided the original species or genus name, authority, year of publication, etymology, and the country where the taxon (species or genus) was originally found. Epithets from which both their meaning and motivation remain elusive are omitted (see text).

apeva. Geoplana apeva Froehlich, 1959. Biology. From the Tupi apeva, or apeba, meaning flattened and widened. It is a reference to the shape of the body: "large, broad and flat" (Froehlich, C.G., 1959). Species from Brazil.

arndti. Dugesia arndti Marcus, 1946. Posthumous homage to the Zoologist Walter Arndt, from the Zoological Museum Berlin (Marcus, 1946). Species from Brazil.

assu. Geoplana assu Froehlich, 1959. Biology. Tupi word meaning big and thick. It is a reference to the body size of the species: "A large, flat and broad species" (Froehlich, C.G., 1959). Species from Brazil.

astraea. Geoplana astraea Marcus, 1951. Biology. From the Latin astr-, astro- (star, star system, constellation. A reference to the resemblance of the dorsum the species to a starry night: "dorsum [...] black [... .] with clear halos" (Marcus, 1951). Species from Brazil.

astrocheta. Dugesia astrocheta Marcus, 1953. Biology. A combination of the Latin astro- (star) and the Greek chaite (long hair). A reference to the aspect of the preserved species resembling a star with radiating setae: "In all the clarified worms the gut contains masses of spongillid tissues and needles" (Marcus, 1953). Species from the Republic of the Congo.

aymara. Geoplana aymara du Bois-Reymond Marcus, 1951. Arbitrary. From Spanish word aimará, meaning a South American Indian person from highland Peru. Species from Peru.

beckeri. Geoplana beckeri Froehlich, 1959. Homage to Mr. Johann Becker, Entomologist at the Museu Nacional do Rio de Janeiro, who collected and donated the type material. Species from Brazil.

bilix. Choeradoplana bilix Marcus, 1951. Biology. From Latin bilis, is, meaning bile. A reference to the yellowish color of the dorsum: "The dorsum is yellowish, with two wide grey-brownish stripes" (Marcus, 1951). Species from Brazil.

caapora. Geoplana caapora Froehlich, 1957. Biology. Tupi word meaning inhabitant of the woods. A reference to the habitat of the species. Species from Brazil.

cafusa. Geoplana cafusa Froehlich, 1956. Biology. From the Portuguese cafuso, or cafuzo, meaning a person of mixed African and Amerindian ancestry. A reference to the brownish color of the dorsum: "The dorsum is black, which fades to brown-grayish towards the sides of the body" (Froehlich, C.G., 1956a). Species from Brazil.

caissara. Geoplana caissara Froehlich, 1955. Biology. A Tupi word meaning coastal inhabitant. A reference to Ubatuba, a Brazilian coastal locality where some of the type specimens were found. Species from Brazil.

caleta. Geoplana caleta Froehlich, 1978. Arbitrary. A Spanish word meaning cove. Species from Chile.

cantuta. Geoplana cantuta du Bois-Reymond Marcus, 1951. Prob. from the popular name of Cantua buxifolia Juss. ex Lam. (Polemoniaceae), a Peruvian flowering plant. Species from Peru.

carvalhoi. Dolichoplana carvalhoi Corrêa, 1947. A homage to João de Paiva Carvalho, who worked at the Instituto de Pesca Marítima and donated the type specimens (Corrêa, 1947). An Asian species introduced into Brazil.

cassula. Geoplana cassula Froehlich, 1955. Biology. From the Portuguese caçula, meaning younger brother. A reference to the small body size: "Small worms with strongly convex dorsum" (Froehlich, E.M., 1955). Species from Brazil.

catua. Choeradoplana catua Froehlich, 1955. Arbitrary. From the Tupi catu, meaning lovely, pleasant. Species from Brazil.

caya. Geoplana caya du Bois-Reymond Marcus, 1951. Prob. a Quichua word meaning morning. Species from Peru.

chalona. Geoplana chalona du Bois-Reymond Marcus, 1951. Prob. from the Spanish word meaning dried lamb meat. Species from Peru.

chanca. Geoplana chanca Froehlich, 1978. Prob. a Spanish word meaning small company of fish-salting. Species from Chile.

chilla. Dugesia chilla Marcus, 1954. Prob. from a native Chilean fox chilla. Species from Chile.

chimbeva. Geoplana chimbeva Froehlich, 1955. Biology. A free composition from the Tupi words tim, meaning snout, and mbé, meaning flattened. A reference to the pointed shape of the anterior extremity of the body: "the body narrows progressively until the anterior extremity of the body" (Froehlich, E.M., 1955). Species from Brazil.

chita. Geoplana chita Froehlich, 1956. Biology. From the Portuguese chita, meaning colored printed cotton fabric of little value. A reference to the dorsal color of the body: "Parenchyma whitish [...], dorsally seen as abundant circular or elliptical areas with various sizes [...]" (Froehlich, C.G., 1956b). Species from Brazil.

chiuna. Geoplana chiuna Froehlich, 1955. Biology. From the Tupi chiuna, meaning black nose. A reference to the black anterior extremity of the body: "The anterior extremity is black" (Froehlich, E.M., 1955). Species from Brazil.

chulpa. Geoplana chulpa du Bois-Reymond Marcus, 1951. Prob. from the Aymara word chullpa, meaning a type of Peruvian funerary tower or ancient sarcophagus. Species from Peru.

conyum. Othelosoma conyum Marcus, 1953. Prob. from the English word cony, a name for the ungulate Syrian rock hyrax, in reference to the color pattern of the back. "The back is rusty brown and becomes gradually lighter towards the ventral side" (Marcus, 1953). Species from the Republic of the Congo.

corderoi. Leucolesma corderoi Marcus, 1948. Homage to the Prof. Dr. Ergasto H. Cordero, from Montevideo (Uruguay) (Marcus, 1948). Species from Brazil.

crioula. Geoplana crioula Froehlich, 1955. Biology. From the Portuguese crioulo, meaning a Brazilian person with African ancestry. A reference to the dark color of the dorsum of the species: "The dorsum is black" (Froehlich, E.M., 1955). Species from Brazil.

dahli. Procerodes dahli Marcus \& du Bois-Reymond Marcus, 1959. Homage to Professor Dr. Erik Dahl, from Lund University (Marcus \& du Bois-Reymond Marcus, 1959). Species from Portugal.

Dinizia. Dinizia Marcus, 1947. A homage to Diva Diniz Corrêa, Professor and marine biologist at University of São Paulo, who collected the type specimen (Corrêa, 1947). Genus from Brazil. 
divae. Geoplana divae Marcus, 1951. Homage to Diva Diniz Corrêa, Professor and marine biologist at University of São Paulo, who collected the type specimen (Marcus, 1951). Species from Brazil.

duca. Geoplana duca Marcus, 1951. Arbitrary. From the motto Non ducor, duco of São Paulo municipality, meaning / am not led, I lead. Species from Brazil.

ectophysa. Dugesia ectophysa Marcus, 1953. Biology. Composition from the Greek prefix ecto-, meaning out of, and the Greek name physa, meaning bubble. A reference to the position of the vesicle out of the penis bulb. "Seminal vesicle lies outside penial bulb" (Marcus, 1953). Species from the Republic of the Congo.

ercilla. Geoplana ercilla Froehlich, 1978. Prob. from the Chilean town Ercilla, ca. $60 \mathrm{~km}$ SE from the collecting locality. Species from Chile.

evelinae. Epithet of many species described by Ernest Marcus. Homage to his wife, Prof. and zoologist Eveline du Bois-Reymond Marcus.

fita. Geoplana fita Froehlich, 1959. Biology. From the Portuguese fita, meaning slender. A reference to the body shape: "A very long and slender species" (Froehlich, C.G., 1959).

fragai. Geoplana fragai Froehlich, 1955. Homage to Dr. Manoel Verçosa Fraga, administrator of the Parque Nacional da Serra dos Órgãos, who facilitated the field work of the author (Froehlich, C.G., 1955b). Species from Brazil.

garua. Geoplana garua du Bois-Reymond Marcus, 1951. Prob. from garúa, Spanish word meaning drizzle. Species from Peru.

gaucha. Geoplana gaucha Froehlich, 1959. Biology. From the Portuguese gaúcho, a inhabitant of the State of Rio Grande do Sul, Brazil. A reference to the State where the species was found (Froehlich, C.G., 1959). Species from Brazil.

glieschi. Geoplana glieschi Froehlich, 1959. Homage to Prof. Dr. Rudolph Gliesch, Professor of Zoology at Federal University of Rio Grande do Sul, in Porto Alegre, Brazil, who collected the type material (Froehlich, C.G., 1959). Species from Brazil.

graetzi. Rhynchodemus graetzi du Bois-Reymond Marcus, 1953. A homage to Prof. Eric A. Graetz, a Marcus's friend from the University of Berlin, who collected the specimens (du Bois-Reymond Marcus, 1953). Species from Panama.

guasa. Liana guasa Froehlich, 1978. Arbitrary. A Quechua word meaning Chilean cowboy. Species from Chile.

Gusana. Gusana Froehlich, 1978. Biology. From the Spanish word gusano, meaning worm. Species from Chile.

harea. Microplana harea Marcus, 1953. Arbitrary. From the English word hare (Froehlich, C.G., pers. comm.). Species from the Republic of the Congo.

hauseri. Geoplana hauseri Froehlich, 1959. A homage to the Hungarian helminthologist Prof. Dr. Josef Hauser, at the University UNISINOS, São Leopoldo, Brazil, who collected the specimens. Species from Brazil.

hymanae. Diporodemus hymanae Froehlich \& Froehlich, 1972. Posthumous homage to the North American zoologist Libbie Henrietta Hyman, from the American Museum of Natural History, New York, EUA (Froehlich, E.M. \& Froehlich, C.G., 1972). Species from Brazil.

hypoglauca. Dugesia hypoglauca Marcus, 1948. Biology. Derived from the Greek prefix hypo-, meaning insufficient, and the Latin name glaucum, meaning bluish-green. A reference to the color of the ventral side of the body: "Dorsum almost uniformly grey-bluish, more or less slaty" (Marcus, 1948). Species from Brazil.

hystrix. Xerapoa hystrix Froehlich, 1955. Biology. From the Latin hystrix, meaning porcupine. A reference to the sensory papillae: "sensory ciliated pits located at the tip of extensible papillae" (Froehlich, C.G., 1955a). Species from Brazil.

Incapora. du Bois-Reymond Marcus, 1953. Biology. Composition of the Quechua word inca, and the Latin porus, meaning pore. A reference to the Peruvian region where the species was found and the two ventral pores present in the species: "with two ventral orificies in the skin" (du Bois-Reymond Marcus, 1953). Genus from Peru.

irua. Geoplana irua du Bois-Reymond Marcus, 1958. Prob. the word irua, meaning friend in Cocama idiom spoken western South America (Vallejos \& Amías, 2015). Species from Peru.

Issoca. Issoca Froehlich, 1955. Biology. From the Tupi yssoca, meaning insect, worm. Genus from Brazil.

jandaia. Issoca jandaia Froehlich, 1955. Arbitrary. From the Tupi jandaia, Psitacidae birds. Species from Brazil.

jandira. Geoplana jandira Froehlich, 1955. Arbitrary. A Tupi word meaning honeybee. Species from Brazil.

jimi. Dugesia jimi Martins, 1970. A homage to Jorge Jim, who collected the species. Species from Brazil.

joia. Geoplana joia Froehlich, 1956b. Biology. From the Portuguese joia, meaning jewel. A reference to the beauty of the species. Species from Brazil.

juliae. Timyma juliae Froehlich, 1978. A homage to author's daughter, Julia Froehlich. Species from Chile.

Kontikia. Kontikia Froehlich, 1955. Biology. From the name of the raft Kon-Tiki, led by Thor Heyerdahl from South America to the Polynesian islands (Froehlich, C.G., pers. comm.). A reference to the exotic condition in Brazil of the type species, Kontikia orana: "Probably, it is an introduced element from the western IndoPacific" (Froehlich, C.G., 1955a). Exotic genus introduced into Brazil.

Iama. Geoplana lama du Bois-Reymond Marcus, 1957. Arbitrary. From the Spanish llama, the South American ruminant mammal Lama glama. Species from Peru.

Iambaya. Geoplana lambaya du Bois-Reymond Marcus, 1958. Prob. from Lambayeque region, in Peru. Species from Peru.

Leucolesma. Leucolesma Marcus, 1948. Biology. Composition from the Greek leukos, meaning white, and the Portuguese lesma, meaning slug. A reference to the body color of the type species of the genus L. corderoi: "The [body] color is white" (Marcus, 1948). Genus from Brazil.

leucophryna. Geoplana leucophryna Marcus, 1951. Biology. Composition of the Greek elements leukos, meaning white, and phryne, meaning toad. It refers to the color of the body: "The body color of the young individuals is light, dorsally almost white" (Marcus, 1951).

Liana. Liana Froehlich, 1978. Biology. From the Spanish liana, meaning climbing vine. It refers to the body shape: "elongated body" (Froehlich, E.M., 1978). Species from Chile.

libbieae. Geoplana libbieae du Bois-Reymond Marcus, 1958. Homage to the North American zoologist Libbie Henrietta Hyman. Species from Peru.

livia. Geoplana livia Froehlich, 1955. Biology. From the Latin lividus, meaning bluish, black and blue. It refers to the body color: "Anterior extremity evenly grayish" (Froehlich, E.M., 1955). Species from Brazil.

marthae. Choeradoplana marthae Froehlich, 1955. Homage to Martha Breuer, from the Department of Zoology of the University of São Paulo, who collected the type specimens (Froehlich, C.G., 1955a). Species from Brazil.

matuta. Geoplana matuta Froehlich, 1955. Biology. A Portuguese word meaning inhabitant of the woods. It refers to the habitat where land planarians typically dwell. Species from Brazil.

Miava. Miava Marcus, 1954. Arbitrary. From the past tense of the Portuguese verb miar, meaning meow, in reference to the behavior of Eveline's cat(s). Genus from Chile. See Fig. 3. 
mirim. Geoplana mirim Froehlich \& Froehlich, 1972. Biology. From the Tupi mirĩ, meaning small. It refers to the body size: "length, 15 mm" (Froehlich, E.M. \& Froehlich, C.G., 1972). Species from Brazil.

misus. Rhynchodemus misus du Bois-Reymond Marcus, 1965. Arbitrary. From the Portuguese call used to catch the attention of cats, mis-mis. Species from Equador. See Fig. 3.

moei. Probursa moei Corrêa, 1960. Homage to Mr. Henry Allen Moe, vice-president and secretary general of the John Simon Guggenheim Memorial Foundation, N.Y., which awarded her a fellowship for studies in the United States (Corrêa, 1960). Species from the USA.

monomyoda. Dugesia monomyoda Marcus, 1953. Biology. Composition of the Greek elements mono-, meaning one, single, and myo-, meaning muscle. It refers to the number of muscle layers: "absence of the inner layer of longitudinal muscles in the outer wall of the pharynx" (Marcus, 1953, p. 25). Species from the Republic of the Congo.

mourei. Geoplana mourei Froehlich, 1956. A homage to Prof. Jesus Santiago Moure, professor at the Federal University of Paraná, for the logistic support he provided to the authors in the field (Froehlich, C.G., 1956b).

nana. Geoplana nana Froehlich, 1956. Biology. A Spanish word meaning tiny. A reference to the size of the worms: "small Geoplana" (Froehlich, C.G., 1956b). Species from Brazil.

nataliae. Geoplana nataliae Froehlich, 1959. Homage to Natália Gabrusewycz, who collected the types (Froehlich, C.G., 1959). Species from Brazil.

Nerpa. Nerpa Marcus, 1948. A Russian-derived word for Pusa sibirica, the Baikal seal. Warm homage to Marcus' wife, whose chubby body resembled a seal. Species from Brazil.

nigra. Geoplana nigra Froehlich, 1959. Biology. From Latin niger, meaning black. A reference to the body color: "evenly black brownish, ventral side grey" (Graff, 1899). Species from Brazil.

nonatoi. Dugesia nonatoi Marcus, 1946. Homage to Edmundo Ferraz Nonato, Professor and researcher at the University of São Paulo (Marcus, 1946). Species from Brazil.

oliverioi. Geoplana oliveiroi Froehlich, 1955. Homage to Olivério Oliveira Pinto, Ornithologist and Eudóxia's father (Froehlich, C.G., 1955b). Species from Brazil.

orana. Kontikia orana Froehlich, 1955. Biology. From the polynesian la Orana Maria, a Paul Gauguin's painting. A reference to the Asian origin of the species: "Zoogeographic distribution of the genus Kontikia embraces mainly the Oriental and Notogeic regions" (Froehlich, C.G., 1955a). An Asian species introduced into Brazil.

parca. Geoplana parca Froehlich, 1955. Prob. from the Latin parcus, meaning scanty, in reference to the only one specimen composing the type-series. Species from Brazil.

pasipha. Geoplana pasipha Marcus, 1951. Arbitrary. From Pasiphaë, a queen of Crete in Greek mythology. Species from Brazil.

pavani. Geoplana pavani Marcus, 1951. Homage to Crodowaldo Pavan, Professor and Geneticist at the University of São Paulo, who collected the type specimens (Marcus, 1951). Species from Brazil.

perereca. Microplana perereca Marcus \& du Bois-Reymond Marcus, 1959. Arbitrary. A Tupi word meaning frog. Species from Portugal.

phocaica. Geoplana phocaica Marcus, 1951. Warm homage to Marcus' wife, whose chubby body resembled a seal. Species from Brazil.

pichuna. Geoplana pichuna du Bois-Reymond Marcus, 1951. Prob. from the Peruvian toponimic Pichuña Hill. Species from Peru.

picta. Geoplana picta Froehlich, 1956. Biology. From the Latin pictus, meaning painted, colored. A reference to the body color: "scattered over the dorsum there are black spots and dots" (Froehlich, C.G., 1956a). Species from Brazil.

pinima. Geoplana pinima Froehlich, 1955. Biology. A Tupi word meaning spotted. A reference to the body color: "[Dorsum with] large dark grey halos, so densely packed that they merge with each other" (Froehlich, E.M., 1955). Species from Brazil.

piptus. Rhynchodemus pictus Marcus, 1952. Biology. From Greek, pipto, meaning to fall. The species was found fallen into the water. Species from Brazil (Froehlich, C.G., pers. comm.).

piranga. Issoca piranga Froehlich, 1955. Biology. A Tupi word meaning red, brownish red. A reference to the body color: "Dorsum with orangish-to-rusty background" (Froehlich, C.G., 1955a). Species from Brazil.

placilla. Geoplana placilla Froehlich, 1978. Arbitrary. Name of a Chilean province. Species from Chile.

plumbea. Geoplana plumbea Froehlich, 1956. Biology. A Portuguese word meaning lead color. A reference to the body color: "Dorsum lead color or brownish" (Froehlich, C.G., 1956b). Species from Brazil.

poca. Geoplana poca Froehlich, 1957. Prob. from the Tupi word poca, meaning to pop, to explode. Species from Brazil.

polecatum. Othelosoma polecatum Marcus, 1953. Prob. from the English word polecat (Mustelidae) (Froehlich, C.G., pers. comm.), a reference to the color pattern of the African polecat. "On the dorsal side there are 4 black stripes, the median ones connected by a finely stippled area, the outer ones with distinct borders" (Marcus, 1953). Species from the Republic of the Congo.

potyra. Issoca potyra Froehlich, 1957. Arbitrary. A Tupi word meaning flower. Species from Brazil.

pugum. Othelosoma pugum Marcus, 1953. Prob. from the English pug, a small, fat, short-haired dog with a flat face. "The anterior end of the body is quite blunt" (Marcus, 1953). Species from the Republic of the Congo.

Puiteca. Puiteca du Bois-Reymond Marcus, 1955. Prob. a funny abridged composite word meaning "don't step onto Teca", prob. proposed as a reply to the name of the mollusk Piseinotecus Marcus, 1955. Genus from Brazil and Australia.

quagga. Geoplana quagga Marcus, 1951. Biology. Name of the extinct equid quagga. A reference to the body color: "Dorsum black [...] anterior $1 / 5^{\text {th }}$ of the body with transverse clear stripes" (Marcus, 1951). Species from Brazil. See Fig. 1.

quenua. Geoplana quenua du Bois-Reymond Marcus, 1958. Prob. derived from the Spanish word quena, a traditional flute of the Andes. Species from Chile. quichua. Geoplana quichua du Bois-Reymond Marcus, 1951. Arbitrary. A Spanish word for referring to the Quechua idiom. Species from Peru.

regia. Geoplana regia Froehlich, 1955. Homage to author's sister, as an alternative to her true name Regina, which was pre-occupied. Species from Brazil.

Rhodax. Rhodax Marcus, 1946. Prob. from the Greek rhodo-, meaning rose, red. "The dorsal color is yellowish-rose [...]. Besides, there are reddish chromatophores (in juveniles)" (Marcus, 1946). Species from Brazil. 
riesteri. Geoplana riesteri Froehlich, 1955. Homage to Albert Riester, German zoologist who described several species collected by Ernest Bresslau. Species from Brazil.

righii. Geoplana righii Froehlich \& Froehlich, 1972. Homage to Gilberto Righi, Professor and researcher at the University of São Paulo, who collected the type material (Froehlich, E.M. \& Froehlich, C.G., 1972). Species from Brazil.

rincona. Dugesia rincona Marcus, 1954. Prob. from the Spanish word rincón, meaning corner. Species from Chile.

rosea. Geoplana rosea Froehlich, 1955. Biology. From the Portuguese rosa, meaning pink. A reference to the body color:"Dorsum [... .] with background pink covered with dark brownish spots" (Froehlich, E.M., 1955). Species from Brazil.

ruca. Microplana ruca Marcus, 1954. Arbitrary. A Mapuche word meaning a housing of the Pampa and Patagonian aborigines. Species from Chile.

rudebecki. Othelosoma rudebecki Marcus, 1955. Homage to Gustaf Rudebeck, Professor at the Lund University, who collected the specimens in South Africa (Marcus, 1955a). Species from South Africa.

ruiva. Geoplana ruiva Froehlich \& Froehlich, 1972. Biology. A Portuguese word meaning red, red-haired. A reference to the body color: "Dorsal side reddish-brown due to brown pigment over a brick-red ground" (Froehlich, E.M. \& Froehlich, C.G., 1972). Species from Brazil.

saegeri. Othelosoma saegeri Marcus, 1955. Homage to H.S. Saeger, chief of the Expedition to the South African Garamba National Park (Marcus, 1955b). Species from the Republic of the Congo.

schubarti. Dugesia schubarti Marcus, 1946. Homage to the German-born, specialist in Diplopoda Otto Schubart, who collected numerous planarians (Marcus, 1946). Species from Brazil.

scius. Rhynchodemus scius du Bois-Reymond Marcus, 1955. Prob. from the Latin scius, meaning knowing, having knowledge. Species from Brazil.

shapra. Geoplana shapra du Bois-Reymond Marcus, 1957. Prob. from the word for referring to the Peruvian Shapra people. Species from Peru.

suva. Geoplana suva Froehlich, 1959. Arbitrary. From Siva, or Shiva, one of the principal Hindu deities. Typographical error. Species from Brazil.

takia. Geoplana takia du Bois-Reymond Marcus, 1951. Prob. from the Quechua word taki, meaning song. Species from Peru.

tamoia. Geoplana tamoia Froehlich, 1955. Homage to the extinct tribe Tamoios, from the Southeast Brazil, where the species was found. Species from Brazil.

tapetilla. Geoplana tapetilla Marcus, 1951. Biology. From the Tupi word tapeti, meaning Brazilian cottontail. A reference to the body color: "Dorso-median light orangish stripe which is bordered with a black stripe on each side" (Marcus, 1951). Species from Brazil.

tapira. Geoplana tapira Froehlich, 1957. Biology. From the name of the municipality Tapiraí, where the species was found: "Locality: Tapiraí, a small village ca. 100 km WSW of the city of São Paulo" (Froehlich, C.G., 1957). Species from Brazil.

taxiarcha. Geoplana taxiarcha Marcus, 1951. Arbitrary. From the Greek taxiarchos, meaning brigadier. Species from Brazil.

Tiddles. Tiddles Marcus, 1963. Arbitrary. A common name for cats in the United Kingdom. Genus from Brazil.

Timyma. Timyma Froehlich, 1978. Biology. Composition of the Tupi words tĩ, meaning nose, and ymé, meaning without. A reference to the body shape:"body ending abruptly in a wide anterior extremity" (Froehlich, E.M., 1978). Genus from Chile.

tinga. Cura tinga Marcus, 1955. Biology. Tupi word meaning white. A reference to the body color: "short auricles which are marked by white spots" (Marcus, 1955a). Species from South Africa.

tirua. Geoplana tirua Froehlich, 1978. Arbitrary. From Tirúa, a Chilean commune of Biobío region. Species from Chile.

toriba. Geoplana toriba Froehlich, 1957. Arbitrary. A Tupi word meaning party, delight Species from Brazil.

trigueira. Geoplana trigueira Froehlich, 1955. Biology. Portuguese word meaning wheat-like colored, brownish. A reference to the body color: "Dorsum with a yellowish background. A dark brownish mid-stripe [... . . Two paramedian light olive-brownish stripes" (Froehlich, E.M., 1955). Species from Brazil.

trina. Geoplana trina Marcus, 1951. Biology. From Latin trinus, meaning in three's. A reference to the body color: "A black mid-stripe and two black lateral stripes" (Marcus, 1951). Species from Brazil.

tuxaua. Geoplana tuxaua Froehlich, 1955. Arbitrary. Tuxaua, tuixaua, or tubixaba, a Tupi word meaning tribal chief. Species from Brazil.

una. Xerapoa una Froehlich, 1955. Biology. A Tupi word meaning black. A reference to the body color: "Dorsum and body margins [...] bright black" (Froehlich, C.G., 1955a). Species from Brazil.

Vatapa. Vatapa Marcus, 1948. Arbitrary. A Portuguese word for a traditional African-Brazilian dish. Genus from Brazil and New Zealand.

velina. Geoplana velina Froehlich, 1955. Homage to Eveline du Bois-Reymond Marcus (as an alternative to the name evelinae, which was pre-ocuppied). Species from Brazil.

vicuna. Geoplana vicuna du Bois-Reymond Marcus, 1951. Prob. from the Spanish word vicuña, meaning the South American camelid Vicugna vicugna. Species from Peru.

voleum. Othesoloma voleum Marcus, 1953. Arbitrary. From vole, name of rodents of the genus Arvicola (Froehlich, C.G., pers. comm.). Species from the Republic of the Congo.

weyrauchi. Geoplana weyrauchi du Bois-Reymond Marcus, 1953. Homage to the German Zoloogist Dr. Wolfgang K. Weyrauch, who conducted zoological samplings in Peru. Species from Peru.

Xerapoa. Xerapoa Froehlich, 1955. Biology. A free composition from the Tupi words xe and rapó, meaning rooting. A reference to the cephalic papillae resembling roots: "worms rised up the cephalic extremity curled up with the distended papillae" (Froehlich, C.G., 1955a). Genus from Brazil.

yara. Geoplana yara Froehlich, 1955. Biology. A Tupi word meaning a green-haired Amazonian mermaid in the Brazilian folklore. A reference to the body color: "Background color of the dorsum orangish [...]. Green pigment on a yellowish mid-stripe, which is very dense in the anterior region" (Froehlich, E.M., 1955). Species from Brazil. See Fig. 2.

yaravi. Microplana yaravi du Bois-Reymond Marcus, 1957. Prob. from the Quechua-derived word harawi, a musical genre. Species from Peru. 